\title{
Physicians' attitudes towards mammography and prophylactic surgery for hereditary breast/ ovarian cancer risk and subsequently published guidelines
}

\author{
Claire Julian-Reynier ${ }^{1}$, François Eisinger ${ }^{2}$, Jean-Paul Moatti ${ }^{1}$ and Hagay Sobol ${ }^{2}$ \\ ${ }^{1}$ INSERM U379, and ${ }^{2}$ INSERM E9939, Paoli-Calmettes Institute, Marseilles, France
}

\begin{abstract}
After a BRCA mutation has been identified in the context of hereditary breast/ ovarian cancer (HBOC), mammographic screening and prophylactic surgery are two of the main options available to those responsible for the clinical management of healthy women. The aim of this study was to describe the attitudes of specialists towards the clinical management of women with an HBOC risk: this information was collected prior to the publication of the recent French guidelines. A random national sample of 1169 French surgeons, gynaecologists and obstetricians was surveyed using a mailed questionnaire, to which 700 of these physicians $(60 \%)$ responded. When dealing with a BRCA mutated woman, $88.6 \%$ of the respondents said they would recommend mammographic screening, but only $27.1 \%$ would recommend that it should be carried out annually from the age of $\mathbf{3 0}$ years onwards, as recommended in the French guidelines; $10.9 \%$ would find it acceptable to propose prophylactic mastectomy from the age of 30 years, and $22.9 \%$ would find it acceptable to propose prophylactic oophorectomy from the age of 35 years. The specialists who agreed with recommending breast/ ovarian cancer genetic testing also had more positive attitudes towards prophylactic mastectomy (adj $O R=3.4,95 \% \mathrm{Cl}=1.4-8.2$ ), as did those who had previously recommended prophylactic mastectomy when gene testing was not yet available (adj $O R=2.06,95 \% \mathrm{Cl}=1.23-3.44)$. The respondents' attitudes towards prophylactic oophorectomy and mastectomy were significantly associated (adj OR $=3.9 ; 95 \% \mathrm{Cl}=\mathbf{2 . 3 - 6 . 5}$ ). Previous recommendation of prophylactic mastectomy was associated $(P<0.01)$ with a higher level of knowledge of breast/ ovarian cancer genetics and with medical practice in this field. French physicians' attitudes towards mammographic screening and prophylactic surgery were not in complete agreement with the subsequently published French guidelines, the impact of which has now to be considered. Constantly evolving knowledge about the efficacy of preventive intervention will give practitioners new elements to integrate into their counselling. European Journal of Human Genetics (2000) 8, 204-208.
\end{abstract}

Keywords: BRCA1; BRCA2; physician; clinical management; guidelines; public health; evaluation; breast cancer

\section{Introduction}

Identification of the BRCA predisposing breast/ovarian cancer genes has given rise to some difficult dilemmas as to what risk information should be conveyed to women with these gene mutations, and what preventive strategies should be

Correspondence: Dr Claire Julian-Reynier, INSERM U379, “Epidemiology and Social Sciences applied to Medical Innovation", Centre Régional de Lutte contre le Cancer, 232 Boulevard Sainte Marguerite,

13273 Marseille cedex 9, France. Tel: +334912235 02;

Fax: + 334912235 04; E-mail: julian@marseille.inserm.fr

Received 6 August 1999; revised 14 October 1999; accepted

11 November 1999 recommended. ${ }^{1-3}$ In this context of uncertainty, the American and French National task forces have decided that certain specific management strategies should be recommended for dealing with the challenge of managing individuals with high risk levels, despite the fact that little scientific evidence is available so far as to the efficacy of the preventive and surveillance options at our disposal. ${ }^{4,5}$ In cases where the lifetime risk of cancer is higher than $40 \%$, two preventive strategies were strongly advised in the French recommendations: an annual mammography from the age of 30 years for women with a hereditary breast cancer risk, and a preventive 
oophorectomy from the age of 35 years for women with a hereditary ovarian cancer risk. Preventive mastectomy might be proposed (but never recommended) from the age of 30 in the case of those with a $60 \%$ lifetime risk of breast cancer, and we now have further evidence as to its efficacy, since the results of the first retrospective study to be published seem to indicate that $90 \%$ of hereditary breast cancers could be prevented by performing a bilateral prophylactic mastectomy. ${ }^{6}$

Prior to publication of the national guidelines, we carried out a French national survey to investigate the attitudes of the specialists most frequently confronted with breast/ ovarian cancers, ie surgeons and gynaeco-obstetricans, to the clinical management of women with an HBOC risk, with a view to determining whether the recommendations published in the guidelines would require physicians to change their customary practices.

\section{Methods}

\section{Sample and procedure}

French physicians specialised in general and gynaecological surgery and in gynaecology and obstetrics were selected for this study from an exhaustive national directory drawn up on the basis of information provided by pharmaceutical companies' marketing agents (Cegedim-direct marketing).

Questionnaires were sent out in 1996 to 1500 physicians corresponding to $17 \%$ of these French specialists $(n=8700)$; 331 were subsequently excluded (incorrect address, relocation or retirement, had transferred to another speciality, refused to participate, had never encountered breast/ovarian cancer in their practice).

\section{Questionnaire}

The respondents' opinions about the management of HBOC were collected using two clinical vignettes, the one involving a woman who was genetically predisposed to breast cancer and the other, a woman who was genetically predisposed to ovarian cancer (see Appendix).

The questionnaire (90 questions) also included personal questions (age, gender, relatives or close friends affected by cancer) and questions about the respondents' occupational characteristics (speciality, kind and size of practice), knowledge questions, and questions about previous experience of making recommendations about prophylactic surgery to women with a cancer risk running in their family and whether they would offer breast cancer genetic testing.

Details of the survey procedure and the knowledge questions used have been described elsewhere. ${ }^{7}$

\section{Statistical analysis}

The SPSS 8.01 statistical package was used for the analysis.

Chi-square and F-tests were used to compare percentages and means in univariate comparisons. Forward logistic regression (Wald test) was used to adjust the determinants of the attitudes for any confounding factors. The dependent variables were mainly the acceptability of prophylactic surgery in the case of a woman with a gene predisposing her to breast/ovarian cancer and secondly, having previously proposed prophylactic surgery in a family risk context.

The statistical significance was defined as a typel error lower than 0.05 . Only variables with a typel error lower than 0.05 were included in the multivariate adjustment models.

\section{Results \\ Sample characteristics}

The overall response rate was 59.9\% (700/1169), ranging from $53.9 \%$ in the case of the surgeons $(n=190)$ to $62.9 \%$ $(n=510)$ in that of the gynaecologists and obstetricians. Their age was 45.4 on average (SD $=7.8$ ) and $46.4 \%$ were women; $22.1 \%$ were working full time in public hospitals.

\section{Mammographic screening}

Among the respondents, $88.6 \%(620 / 700)$ said they would recommend mammographic screening. The majority would recommend this screening every year and a minority every two years (Figure1). A very small percentage would even recommend this screening every 6 months. Annual screening would be recommended by $14.4 \%(101 / 700)$ from the age of 25 years onwards, in $27.1 \%$ (190/700) from the age of 30 years onwards, and $40.5 \%$ from the age of 35 years old onwards ( $n=198)$.

\section{Acceptability and previous recommendation of prophylactic mastectomy}

Among the respondents, $18.7 \%$ (131/700) said they would find prophylactic mastectomy acceptable in the case of a woman with a breast cancer gene mutation, but only $10.9 \%$ $(76 / 700)$ agreed with this procedure being adopted from the age of 30 years. In the context of a cancer risk running in the family, $25.4 \%$ (178/700) had previously suggested a prophylactic mastectomy to at least one of their patients before any

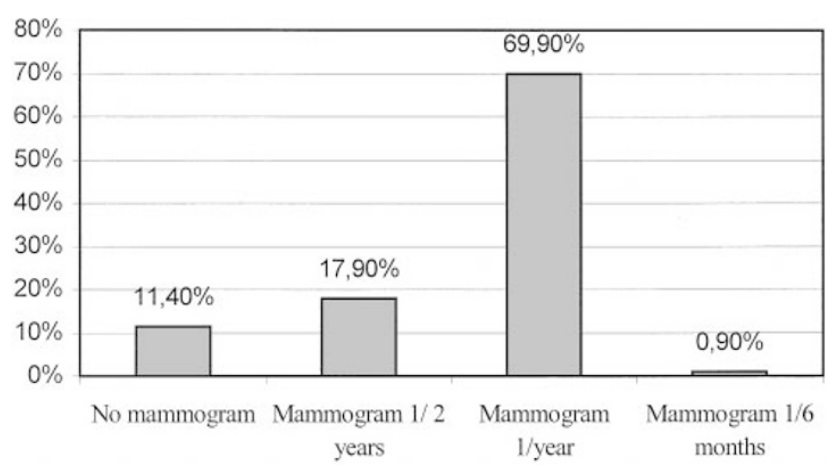

Figure 1 Specialists' recommendations for mammographic screening in the context of hereditary breast ovarian cancer risk $(n=700)$. 
genetic testing became available: $37.9 \%$ of the gynaecologist surgeons, and $28.8 \%$ of the general surgeons.

\section{Acceptability and previous recommendation of prophylactic oophorectomy}

Among the respondents, $8.1 \%(57 / 700)$ said they would never find prophylactic oophorectomy acceptable in the case of a woman with a genetic predisposition to ovarian cancer (even if she already had as many children as she wanted and hormonal replacement therapy was available) and $91.9 \%$ $(643 / 700)$ gave different age limits for the threshold they considered acceptable. Only $22.9 \%$ (160/700) agreed with applying this procedure from the age of 35 years. In the context of a cancer risk running in the family, $28.6 \%$ of the respondents (200/700) had previously recommended prophylactic oophorectomy to at least one of their patients before genetic testing became available.

\section{Determinants of attitudes and practices as far as prophylactic surgery is concerned}

In the univariate comparisons and after multivariate adjustment, three variables were found to be significantly associated with a higher acceptability of prophylactic mastectomy: previous recommendation of prophylactic mastectomy before genetic testing became available (adj $\mathrm{OR}=2.1 ; 95 \% \mathrm{Cl}=1.2-3.4$ ), a positive attitude toward breast/cancer genetic testing (adj OR $=3.4 ; \quad 95 \%$ $\mathrm{Cl}=1.4-8.2$ ), and a positive attitude towards prophylactic oophorectomy (adj OR $=3.9 ; 95 \% \mathrm{Cl}=2.3-6.5$ ).

Eight variables were significantly $(P<0.05)$ associated with having previously recommended prophylactic mastectomy in a family context (Table1). After multivariate adjustment, four variables were still significant (Table2). The physicians who had previously suggested prophylactic mastectomy differed in the following respects from those who had not: they had a higher level of knowledge about breast/ovarian cancer genetics $(P=0.02)$, and a more positive opinion about cancer genetic testing ( $P=0.03$ ). They al so had more patients with breast cancer in their practice than their colleagues and were working less frequently full time in public hospitals (Table2). The effects of age, gender and speciality (Table1) were no longer significant after multivariate adjustment.

\section{Discussion}

Here we established first that the majority of the French gynaeco-obstetricians and surgeons surveyed were likely to comply with the national recommendations subsequently published, ${ }^{5}$ which advise annual mammographic surveillance for women with a BRCA1/2 mutation, since this recommendation was in line with their spontaneous a priori attitudes. The physicians' opinions about the age at which

Table 1 Previous proposal of prophylactic mastectomy: univariate comparisons

\begin{tabular}{|c|c|c|c|c|c|}
\hline & $\begin{array}{l}\text { Yes } \\
n\end{array}$ & $\%$ & $\begin{array}{l}\text { stector } \\
\text { no }\end{array}$ & $\%$ & $P^{a}$ \\
\hline $\begin{array}{l}\text { Speciality } \\
\text { Surgeons ( } n=190) \\
\text { Gynaeco-obstetricians }(n=510)\end{array}$ & $\begin{array}{r}60 \\
118\end{array}$ & $\begin{array}{l}31.6 \\
23.4\end{array}$ & $\begin{array}{l}130 \\
386\end{array}$ & $\begin{array}{l}68.4 \\
76.6\end{array}$ & 0.03 \\
\hline $\begin{array}{l}\text { Full-time public hospitals } \\
\qquad \begin{array}{l}\text { Yes }(n=155) \\
\text { No }(n=545)\end{array}\end{array}$ & $\begin{array}{r}26 \\
152\end{array}$ & $\begin{array}{l}16.8 \\
27.9\end{array}$ & $\begin{array}{l}129 \\
393\end{array}$ & $\begin{array}{l}83.2 \\
72.1\end{array}$ & 0.005 \\
\hline $\begin{array}{l}\text { Gender } \\
\text { Male }(n=371) \\
\text { Female }(n=325)\end{array}$ & $\begin{array}{r}106 \\
71\end{array}$ & $\begin{array}{l}28.6 \\
21.8\end{array}$ & $\begin{array}{l}265 \\
254\end{array}$ & $\begin{array}{l}71.4 \\
78.2\end{array}$ & 0.04 \\
\hline $\begin{array}{l}\text { Breast cancers seen annually } \\
\qquad \begin{array}{l}0-5(n=373) \\
6-10(n=133) \\
>10(n=157)\end{array}\end{array}$ & $\begin{array}{l}70 \\
34 \\
65\end{array}$ & $\begin{array}{l}18.8 \\
25.6 \\
41.4\end{array}$ & $\begin{array}{r}303 \\
99 \\
92\end{array}$ & $\begin{array}{l}81.2 \\
74.4 \\
58.6\end{array}$ & $\lessdot 0.001$ \\
\hline $\begin{array}{l}\text { Often read international literature } \\
\text { Yes }(n=292) \\
\text { No }(n=408)\end{array}$ & $\begin{array}{l}88 \\
90\end{array}$ & $\begin{array}{l}30.1 \\
22.1\end{array}$ & $\begin{array}{l}204 \\
318\end{array}$ & $\begin{array}{l}69.9 \\
77.9\end{array}$ & 0.02 \\
\hline $\begin{array}{l}\text { Would offer breast cancer genetic testing } \\
\text { Yes }(n=292) \\
\text { No }(n=408)\end{array}$ & $\begin{array}{r}154 \\
24\end{array}$ & $\begin{array}{l}27.5 \\
17.1\end{array}$ & $\begin{array}{l}406 \\
116\end{array}$ & $\begin{array}{l}72.5 \\
82.9\end{array}$ & 0.01 \\
\hline No $(n=408)$ & $\begin{array}{l}\text { Yes } \\
X\end{array}$ & SD & $\begin{array}{l}\text { stector } \\
\text { No }\end{array}$ & SD & $\mathrm{P}^{\mathrm{a}}$ \\
\hline $\begin{array}{l}\text { Age } \\
\text { Breast/ovarian cancer genetics knowledge } \\
\text { (continuous score from } 0 \text { to } 7 \text { ) }\end{array}$ & $\begin{array}{r}46.8 \\
4.0\end{array}$ & $\begin{array}{l}7.5 \\
1.9\end{array}$ & $\begin{array}{r}44.9 \\
3.5\end{array}$ & $\begin{array}{l}7.5 \\
1.9\end{array}$ & $\begin{array}{l}0.004 \\
0.007\end{array}$ \\
\hline
\end{tabular}

${ }^{\mathrm{a}} \chi^{2}$ test; ${ }^{\mathrm{b}} \mathrm{F}$ test. 
Table 2 Previous proposal for prophylactic mastectomy: multivariate adjustment by logistic regression (SPSS 8.0 Enter procedure)

\begin{tabular}{|c|c|c|c|}
\hline & Adjusted odds ratio OR & $95 \%$ confidence interval & $\mathrm{P}^{\mathrm{a}}$ \\
\hline $\begin{array}{l}\text { Speciality } \\
\text { Surgeons (code } 0, n=190 \text { ) } \\
\text { Gynaeco-obstetricians (code } 1, n=510 \text { ) }\end{array}$ & 0.81 & $(0.49-1.33)$ & 0.397 \\
\hline $\begin{array}{l}\text { Full-time public hospitals } \\
\text { Yes (code } 1, n=155) \\
\text { No (code } 0, n=545 \text { ) }\end{array}$ & 0.53 & $(0.32-0.90)$ & 0.018 \\
\hline $\begin{array}{l}\text { Gender } \\
\quad \text { Male (code } 0, n=371 \text { ) } \\
\quad \text { Female (code 1, n=325) }\end{array}$ & 0.85 & $(0.54-1.34)$ & 0.489 \\
\hline $\begin{array}{l}\text { Breast cancers seen annually } \\
0-5 \text { (code } 0, n=373 \text { ) (reference category) } \\
\quad 6-10 \text { (code } 1, n=133)(1 \text { vs } 0 \text { and } 2) \\
\quad>10 \text { (code } 2, n=157) \text { ( } 2 \text { vs } 0 \text { and } 1)\end{array}$ & $\begin{array}{l}1.33 \\
2.34\end{array}$ & $\begin{array}{l}(0.82-2.17) \\
(1.44-3.78)\end{array}$ & $\begin{array}{r}0.002 \\
0.254 \\
\varangle .001\end{array}$ \\
\hline $\begin{array}{l}\text { Would offer breast cancer genetic testing } \\
\text { Yes (code } 1, n=560) \\
\text { No (code } 0, n=140)\end{array}$ & 1.92 & $(1.14-3.23)$ & 0.014 \\
\hline $\begin{array}{l}\text { Age (continuous variable) } \\
\text { Breast/ovarian cancer genetics knowledge } \\
\text { (continuous score from } 0 \text { to } 7 \text { ) }\end{array}$ & $\begin{array}{l}1.01 \\
1.15\end{array}$ & $\begin{array}{l}(0.99-1.04) \\
(1.04-1.27)\end{array}$ & $\begin{array}{l}0.168 \\
0.008\end{array}$ \\
\hline
\end{tabular}

${ }^{\mathrm{a}} \mathrm{P}$ value corresponding to Wald test; ${ }^{b}$ due to co-linearity between reading international literature and knowledge, only knowledge was included in the model.

this surveillance should begin were variable, since the majority recommended beginning surveillance on patients from age of 35 years, whereas the recommendations stipulated 30 years. The second point worth mentioning is the physicians' a priori attitude towards prophylactic surgery at an early age, in the case of both mastectomy and oophorectomy. The acceptability of these two procedures was found to be linked, since the physicians who were in favour of prophylactic oophorectomy were also in favour of prophylactic mastectomy. Those physicians who were in favour of prophylactic surgery tended more frequently to have previously recommended this procedure in a family context and had on average more positive opinions about breast cancer genetic testing. Previous recommendations for prophylactic surgery depended on the characteristics of the physicians' practice, and was also associated with a higher level of knowledge of breast/ovarian cancer genetics (Table2).

The response rate of $60 \%$ was comparable to those obtained in other published medical surveys, in which the response rates varied between $52 \%$ in the case of surgeons questioned on the topic of preventive mastectomy, ${ }^{8}$ and $64.8 \%$ when monetary incentives were offered. ${ }^{9}$ Our respondents were more frequently women, and as reported previously, ${ }^{9}$ they presumably felt more closely concerned by the issues investigated than the non-respondents.

There was consensus about the need for annual mammographic surveillance among the French and US task forces, ${ }^{10}$ although its efficacy has not actually been demonstrated so far. The underlying hypothesis adopted by the respective task forces was that even if the efficacy of mammograms as a means of detecting BRCA-related breast cancer has not yet been definitely established, it may nevertheless be efficacious. Since the negative side-effects of mammography are likely to be low, this surveillance constitutes a potentially helpful tool for use on gene positive women, and the physicians who participated in this survey probably shared this viewpoint.

Few French physicians recommended prophylactic surgery at an early age, even in the context of gene-positive women: only $10.9 \%$ and $22.9 \%$ said they would find prophylactic mastectomy acceptable from the age of 30 years and oophorectomy from the age of 35, respectively. North American physicians seem to have a more positive opinion about prophylactic mastectomy, since $29 \%$ of a group of obstetricians/gynaecologists and as many as $50 \%$ of the general surgeons who participated declared that they would recommend this option for a woman testing positive. ${ }^{11}$ In another survey in a family risk context, ie when no DNA analysis has been carried out, $81 \%$ of the US plastic surgeons questioned declared that they had recommended the procedure, as compared with $38.8 \%$ of the general surgeons and $17.7 \%$ of the gynaecologists. ${ }^{8}$ Our results show that French surgeons seemed to recommend this procedure less frequently in the same family risk context, since only $31.6 \%$ had done so (37.9\% of the gynaecologist surgeons, and $28.8 \%$ of the general surgeons). Gynaecologist surgeons' activities are likely to differ in countries with less breast surgery practice, such as the US and United Kingdom, than in France where they deal with both female genital organs and breasts. Other surveys carried out on women attending cancer genetic clinics have shown a similar lack of enthusiasm about this procedure among French ${ }^{12}$ and North American women. ${ }^{11}$

In our survey, the specialists who had previously proposed prophylactic mastectomy ten ded to work less exclusively in a public hospital setting and encountered more breast cancers in their practice. They were more in favour of breast cancer 
genetic testing and more knowledgeable about breast/ovarian cancer genetic issues. In Geller's survey, the effect of knowledge of this kind was not tested and the main determinant of prophylactic recommendations was found to be the physician's speciality, since the surgeons were more in favour of mastectomy than their colleagues, which may be partly attributable to the effects of specialised knowledge. ${ }^{11}$ Knowing more about breast/ovarian cancer genetics is likely to be associated with a higher acceptability rate of prophylactic surgery, mainly because the limitations of mammographic screening will be better understood by the more knowledgeable practitioners.

These French physicians' attitudes towards mammographic screening and prophylactic surgery were not in complete agreement with the subsequently published guidelines and the lack of 'good medical practice' reference guidelines may explain some of these results. Constantly evolving knowledge about the efficacy of preventive surgery ${ }^{6}$ and of other preventive interventions is likely to introduce new elements that have to be discussed between patients and practitioners. The issue of non-directive counselling is clearly to be considered but the available options should at least be raised for discussion. Our results clearly show that the attitudes of the physicians are related to their experience and knowledge. Considering the low frequency of BRCA1/2 mutations, their clinical management has to be monitored by highly informed practitioners who constantly apply their knowledge of the field. Further surveys are now needed to monitor evolving trends in physicians' attitudes, intentions and practices and the effect on patients' choices and preferences as far as their own clinical management is concerned.

\section{Acknowledgements}

We thank all the physicians who participated in this survey, in particular those who agreed to participate in the preliminary evaluation of the questionnaire, and the medical associations who encouraged this study (French Association of Surgery, National Gynaecologists' and Obstetricians' College, National Federation of Cancer Centers, Societies of Gynaecology and Cancer Gynaecology, French section of the European Society of Oncological Surgery, and the Society of Senology and Breast Pathology). We thank Mrs Françoise Chabal and Mrs Angèle Silvestri for their technical help. This study was funded by the National Institute for Health and M edical Research (Decision No.4M612C) and the Research Association against Cancer.

\section{References}

1 Couch FJ, Hartmann LC: BRCA1 testing advances and retreats. JAMA 1998; 279: 955-956.

2 Parmigiani G, Berry DA, Aguilar O: Determining carrier probabilities for breast cancer-susceptibility genes BRCA1 and BRCA2. Am J Hum Genet 1998; 62: 145-158.

3 Ford D, Easton DF, Stratton $M$ et al: Genetic heterogeneity and penetrance analysis of the BRCA1 and BRCA2 genes in breast cancer families. Am J Hum Genet 1998; 62: 676-689.
4 Burke W, Daly M, Garber J et al: Recommendations for follow-up care of individuals with an inherited predisposition to cancer II. BRCA1 and BRCA2. JAMA 1997; 277: 997-1003.

5 Eisinger $F$, Alby N, Bremond A et al: Recommendations for medical management of hereditary breast and ovarian cancer. (The French National Ad Hoc Committee). Ann Oncol 1998; 9: 939-950.

6 Hartmann LC, Schaid DJ, Woods JE et al: Efficacy of bilateral prophylactic mastectomy in women with a family history of breast cancer (see comments). N Engl J Med 1999; 340(2): 77-84.

7 Julian-Reynier C, Eisinger F, Moatti J-P, Sobol H: French physicians' knowledge about hereditary breast/ovarian cancer: the need for continuous vocational training in genetics. Community Genetics (in press).

8 Houn F, Helzlouer KJ, Friedman NB, Stefanek M: The practice of prophylactic mastectomy: a survey of Maryland surgeons. Am J Pub Health 1995; 85(6): 801-805.

9 Tambor ES, Chase GA, Faden RR, Geller G, Hofman KJ, Holtzman NA: Improving response rates through incentive and follow-up: the effect on a survey of physicians' knowledge of genetics. Am J Pub Health 1993; 83(11): 1599-1603.

10 Eisinger F, Geller G, Burke W, Holtzman NA: Cultural basis for differences between US and French clinical recommendations for women at increased risk of breast and ovarian cancer. Lancet 1999; 353: 919-920.

11 Geller G, Bernhardt BA, Doksum T, Helzlsouer KJ, Wilcox P, Holtzman A: Decision-making about breast cancer susceptibility testing: how similar are the attitudes of physicians, nurse practitioners, and at-risk women? J Clin Oncol 1998; 16(8): 2868-2876.

12 Eisinger F, Julian-Reynier C, Stoppa-Lyonnet D et al: Breast and ovarian cancer prone women and prophylactic surgery temptation. J Clin Oncol 1998; 16(7): 2573-2574.

\section{Appendix}

\section{Clinical vignette1}

Yvonne D... is 25 years old. Her mother was affected with breast cancer when she was aged 39 and her sister when she was 35. After DNA analysis of Yvonne's blood sample, a genetic predisposition to breast cancer is detected, giving a $60 \%$ risk of breast cancer by the age of 50 and an $85 \%$ risk by the age of 80 .

What clinical management would you recommend (mammography every 6 months, every year, every 2 years, prophylactic mastectomy with breast reconstruction, no surveillance for the moment)?

From what age would you propose mammography $(25,30$, 35, 40, 45, 50 years, or never)?

If you think a prophylactic mastectomy might be recommended, from what age (choice of answer as above)?

\section{Clinical vignette2}

Mrs Anaiis V... mother and both aunts died of ovarian cancer before the age of 60 . DNA analysis shows the existence of a very high risk of ovarian cancer in Mrs V. If we assume that Mrs V. has had as many children as she wants and that you are able to give her hormonal replacement therapy, at what age would you suggest starting this procedure $(25,30,35,40$, 45,50 years, or never)? 